\title{
LIVRO DO DESASSOSSEGO: TRANSLATING, READING, AND DECIPHERING THE TEXT
}

\author{
Richard Zenith
}

Independent Researcher and Translator

AвsтRACт: This article develops Richard Zenith's views as the editor and translator of Livro do Desassossego and his useful reflections on authorship, editing and translating. It also presents paradigmatic examples of the difficulties of reading certain parts of $L d D$ as well as an analysis of how these textual variants can alter the (ficticious) authorship, editing and translation criteria of this work in an international context.

Keywords: Livro do Desassosego, editor, translator, English.

\section{LiVRO DO DESASSOSSEGO:}

TRADUCIR, LEER Y DESCIFRAR EL TEXTO

Resumen: El presente artículo desarrolla la perspectiva de Richard Zenith como editor y traductor del Livro do Desassossego, ofreciendo en clave testimonial útiles reflexiones sobre los conceptos de autoría, edición y traducción. Asimismo, presenta ejemplos paradigmáticos de las dificultades de lectura de algunos fragmentos del Livro, comentando cómo estas variantes textuales pueden alterar los criterios de autoría (ficticia), edición y traducción de la obra en un contexto internacional.

Palabras clave: Livro do Desassosego, editor, traductor, inglés.

When I told him that I had neither the time nor the inclination to write a properly scholarly paper, Antonio Sáez Delgado encouraged me to write something, anything, about my experience as a translator and editor of Fernando Pessoa's greatest prose work. I still hesitated, since explanations about one's own editorial work — whether scholarly or informal - can hardly help but be self-justificatory. The best people to write, with objective rigor, about the various editions (in Portuguese) and translations (into other languages) of the Livro do Desassossego are surely not the book's editors and translators. With that forewarning, I will proceed with a personal account of my relationship to the L. do D. as a translator and editor, showing how the two tasks have been interconnected. I will extend my discussion by suggesting that an editor, even when not a translator, will do well to read closely, intimately, in the manner of a translator, in order to more accurately decipher what Pessoa wrote. 
I. I came to the Livro do Desassossego first as a reader, then a translator. Editions of the work had already appeared in Spanish, German, French and Italian, but none in English. It turned out that three other translators had the same belated idea as me, and so four different English versions of the book came out almost simultaneously, in I99i.

Most of the initial translations, into whatever language, offered a large selection of passages included in the first Portuguese edition, published by Edições Ática in 1982 (Pessoa 1982). My intention was to translate the complete work, but «complete» proved to be a slippery concept. In I990-9I, Teresa Sobral Cunha, who had collaborated on the first edition, brought out her own edition (Editorial Presença), which included over one hundred previously unpublished texts (Cunha 1990). Some of the new passages obviously belonged in the book, others seemed like they might belong, and still others struck me as probably extraneous. My first foray into the Pessoa archive at the National Library of Portugal had no other purpose than to locate those new texts and to try to determine if the author indeed intended them for the Livro do Desassossego. This turned out to be like searching for needles in a haystack, partly because Pessoa's handwriting is sometimes scarcely readable, and partly because his writing habits were anarchical, such that $L$. do D. texts are scattered through large swathes of the archive.

I found most of the texts I was looking for and discovered that only a few of them were labeled or had other characteristics explicitly identifying them as passages from L. do D., but my translation included close to forty of the other new texts published in the Presença edition (Cunha 1990), because their style and subject matter strongly suggested that they also belonged to the book. Strongly suggested to me, of course, and I made sure to indicate their uncertain, conjectural status in the endnotes.

My English version also included several short, conjectural passages that had never been published in any language and one longer, likewise never published passage (Figure I) that was very definitely written for the L. do D. It begins with a declaration of indifferent tedium: «Já me cansa a rua, mas não, não me cansa - tudo é rua na vida» [I'm tired of the street, but no, I'm not tired of it - life is nothing but streets]. And it ends with three sentences (Figure 2) that marvelously state Bernardo Soares's highest literary ambition, and his total lack of worldly ambition: 
Translating, reading, and deciphering the text

67

Quem me dera que de mim ficasse uma frase, uma coisa dita de que se dissesse, Bem feito!, como os números que vou inscrevendo, copiando-os, no livro da minha vida inteira.

Nunca deixarei, creio, de ser ajudante de guarda-livros de um armazém de fazendas. Desejo, com uma sinceridade que é feroz, não passar nunca a guarda-livros (Pessoa i998: text 379).

[If only a phrase of mine could remain, just one thing I've written that would make people say «Well done!», like the numbers I duly register, copying them in the book of my entire life.

I suppose I'll always be an assistant bookkeeper in a fabric warehouse. I hope, with absolute sincerity, never to be promoted to head bookkeeper] (Pessoa 2002: text 379).

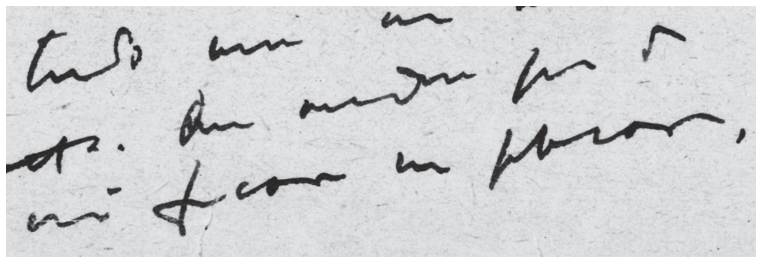

FiguRE i. BNP E3/I38-63.

Buma caive noto " fur ra knaerons a hino fo mithe
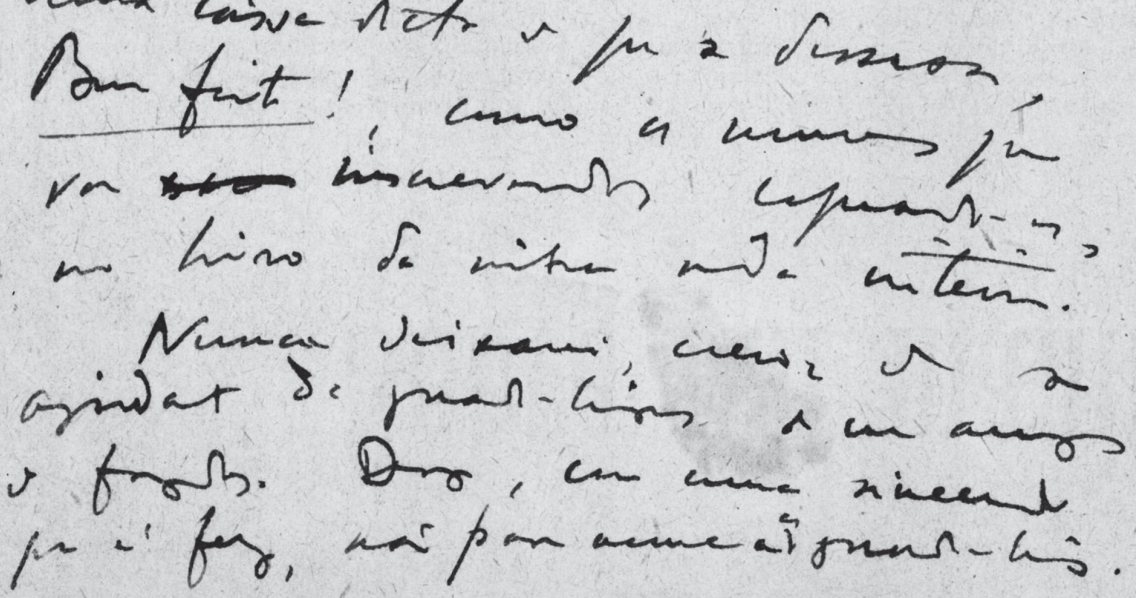

FIGURE 2. Details of BNP E3/I3 $38-63$, containing the last three sentences of the passage.

Abriu, 5 (20I6): 65-77

ISSN: 20I4-8526, e-ISSN: 20I4-8534. DOI: 10.1344/abriu2or6.5.5 
Pessoa's handwriting is not always a challenge, but in this case it was, and since I was a complete novice at deciphering it, I sought the help of several Pessoa scholars. Not through their fault, but because of my own inexperience, my reading of the original — which remained unpublished, as my English edition was monolingual — was not brilliant, to say the least! Deducing from my translation just how faulty it was (I refer to my original translation, not the one cited above), Teresa Sobral Cunha published a considerably improved reading of the passage in Colóquio Letras (Cunha 1993: 220), but that was only the second leg of a long textual journey. I made a number of additional improvements in the reading of the passage included in my edition of the Livro do Desassossego published by Assírio \& Alvim in 1998 (Pessoa I998) — changing TSC's «Que mudou que de mim ficasse» to «Quem me dera que de mim ficasse», for instance (Figure 2) - and still other improvements in the eighth edition of this work (Pessoa 2009), nearly all of which were incorporated in TSC's most recent edition (Pessoa 20I3), though there are several words we disagree on.

In the same way that translators learn from each other, so do editors. They end up collaborating, even if they are never in direct contact. Were it not for the combined efforts of various scholars and researchers, along with the occasional contributions of «amateurs» (and «professionals», I submit, do well to preserve their amatory relationship to the work they pursue), Pessoa's published literary oeuvre would be a far more uncertain, pitfall-ridden territory in which to walk. For no part of that territory is this truer than for the L. do D.

2. In the late ig9os, due to changes in Europe's copyright laws, Pessoa returned to the private domain. His heirs constituted Assírio \& Alvim as their agents, and the publishing house undertook its own edition of Pessoa's works in Portugal. I was commissioned to prepare its edition of the Livro do Desassossego. For the transcriptions of the manuscripts, I was (and am) enormously grateful to the editions that preceded mine, and grateful as well to experienced decipherers who advised me, such as Teresa Rita Lopes. Finding myself abruptly thrust into the sea of Pessoa's manuscripts, it was sink or swim, and I quickly — necessarily — developed a skill for deciphering. The first Assírio \& Alvim edition included several hundred large and small improvements in the readings of the originals. But had the tables been turned — had I collaborated on the original Ática edition - then whoever came after me could point to «several hundred large and small improvements in the readings», or perhaps more. Furthermore, I proposed some new readings that were later corrected by others or that I my- 
self corrected in subsequent editions, as I became increasingly familiar with Pessoa's writing mind and habits, as well as his writing hand.

Like dancing, acrobatics, or tennis, deciphering requires concentrated practice; there is no particular mystery to the task, nor is there anything properly intellectual about it. Perhaps it is true, however, that certain people have a natural talent for deciphering, just as some people have a gift for dancing or for acrobatics.

For the organization of the material included in my edition of the L. do D., I was somewhat indebted to the order I had established for my initial translation, The Book of Disquietude (Pessoa 1991), which in turn owed a small debt to Il libro dell'inquietudine (Pessoa I986), edited and translated by Maria José de Lancastre and Antonio Tabucchi. Theirs is an anthological edition, including only about half of the passages in my English edition, and their ordering of the material has little to do with mine, except in one important respect. They concentrated, at the beginning of the book, a number of passages that establish the fiction of the Rua dos Douradores, where Bernardo Soares lives — in a fourth-floor rented room - and where he works, at the fabric warehouse of Vasques \& Co. That street is also where he writes his «autobiografia sem factos» [factless autoiography], both in his rented room and at his place of employment, when he can steal time from his duties as an assistant bookkeeper.

Since Pessoa clearly indicated, in the last years of his life, that he intended to publish a single L. do D., fictionally authored by Bernardo Soares, I agreed with Lancastre and Tabucchi's strategy of giving prominence to the «biography» of this narrator. My reasons for rejecting multiple authorship (the main reason being that Pessoa himself rejected it), as well as my reasons for not attempting to order the material chronologically (though this is surely the soundest approach for a critical edition; mine are readers' editions) are stated in the prefaces to my various editions of $L$. do D. in Portuguese and English, and I will not repeat myself here.

I will point out, however, that the passage labeled «trecho inicial» (the opening passage in my editions) was the author's masterstroke for uniting, as far as possible, the disparate styles of the book behind a protagonist whose method for coping in a world bereft of certainties is through renunciation, contemplation, and writing about what he contemplates. Actually, this passage does not create unity; it simply foregrounds the book's unity, or as much unity as it contains, by characterizing the essence of the narrating protagonist who is present during every phase of the book's long process of composition, before and after 
Pessoa invented his occupation as an assistant bookkeeper. That «initial passage» is the reader's best key for entering into the work.

3. In the year 1999 I began working on a new English edition, based on my Portuguese edition. Besides adding some new passages and deleting or reordering some of the old ones, I thoroughly revised the translation, correcting outright errors and improving the prose, trying to make it read, for English-language readers, the way the $L$. do D. reads for Portuguese-language readers. This required far more toil than I had anticipated, partly because it involved reexamining the manuscripts.

The first time around translating, when I asked my Portuguese friends about certain odd, unlikely sounding phrases in the L. do D., they said, «That's how Fernando Pessoa writes!» The second time around, now far more familiarized with Pessoa's prose, I realized, in certain cases, that that was not how he writes. And I went back to the manuscripts. I had studied them all when preparing the Assírio \& Alvim edition of the L. do D., and I revised many of the readings, as I mentioned. But many other deficient readings had escaped my notice. Published texts gain a false authority; the readings are presumed to be innocent (correct) until proven guilty (erroneous). The act of translating, or retranslating, the L. do D., led me to detect a number of «guilty» readings.

In the passage that begins «Hoje, como me oprimisse a sensação do corpo» [Today, feeling almost physically ill], for instance, the first two sentences of the last paragraph had been read as:

Uns governam o mundo, outros são o mundo. Entre um milionario americano, com bens na Inglaterra ou Suissa e o chefe Socialista da aldeia — não ha differença de qualidade, mas apenas de quantidade (Pessoa I982: v. I, p. I20).

Which I had translated as:

Some govern the world, others are the world. Between an American millionaire, with assets in England or Switzerland, and the Socialist leader of a small town, there's a difference in quantity but not of quality (Pessoa I99I: I8).

Reconsidering my translation a few years later, the terms of the comparison struck me as far-fetched. It may be that rich Americans had Swiss bank accounts already in Pessoa's day, but why compare them to small-town Social- 


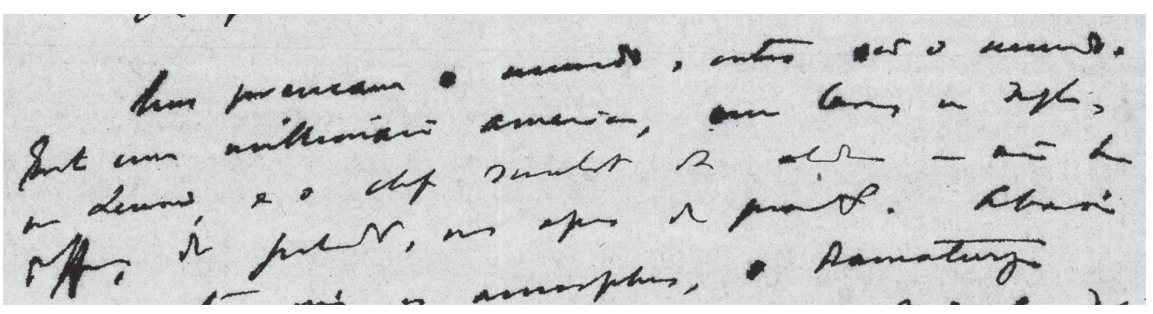

Figure 3. Detail of BNP E3/I-64.

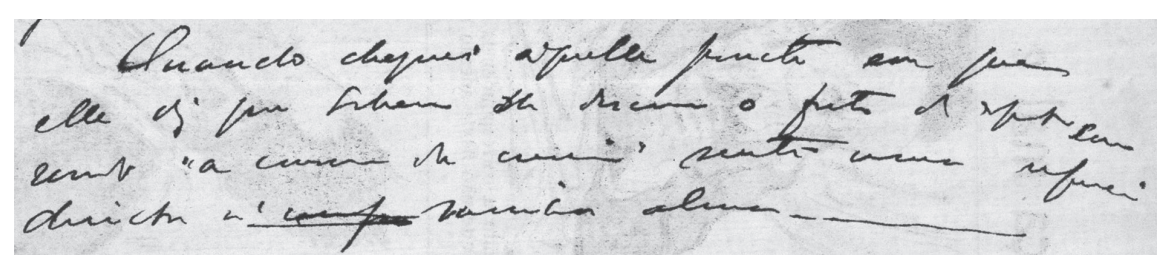

Figure 4. Detail of BNP E3/5-46.

ist mayors? Returning to the original manuscript, it quickly dawned on me that the word transcribed as «Suissa» was actually «Lenine» (see Figure 3).

I felt certain that «com bens na Inglaterra» was also not right, but it took me a few weeks to figure out what Pessoa had actually written: «um Cesar ou Napoleão». The corrected reading was reflected in my English translation for Penguin — «Between an American millionaire, a Caesar or Napoleon, or Lenin, and the Socialist leader of a small town» etc. (Pessoa 200 I: text 24) — before it was corrected in the fourth printing of my Portuguese edition (2003), like so: «Entre um milionário americano, um César ou Napoleão, ou Lenine, e o chefe socialista da aldeia», etc.

One more example... When reviewing my translation of the passage that begins «Foi sempre com desgosto que li no diário de Amiel as referências» [It has always disappointed me to read the allusions in Amiel's diary], I stumbled over the sentence that read, in Portuguese: «Quando cheguei àquele ponto [no diário de Amiel] em que ele diz que sobre ele desceu o fruto do espírito como sendo "a consciência da consciência”, senti uma referência directa à minha alma» [When I came to the passage where he says that the fruit of the mind descended on him like «the consciousness of consciousness», I felt it as a direct reference to my soul] (Figure 4 ). 
I had been unable to make a convincing translation of the words I have italicized, and no wonder: their syntax is murky, at best, and murky, too, is the meaning of the phrase. Consulting the volume of Amiel's diary in Pessoa's personal library, it was easy to correct the reading of the manuscript to: «ele diz que Scherer lhe descreveu o fruto do espírito como sendo» [he says that Scherer described the fruit of the mind], etc. (Actually, Pessoa had misremembered what he read. Edmond Scherer, a friend of Amiel, spoke to him of «l'intelligence de la conscience»; it was Amiel himself who spoke of «la conscience de la conscience».)

4. My experience translating the L. do D. proved to me the crucial importance of closely reading for meaning and syntax so as to accurately decipher Pessoa's handwriting. Sometimes, even before consulting the original manuscript, one can understand where a transcription has gone wrong and even what the right word or words should be. Speaking of syntax, there is an extraordinary passage from the $L$. do $D$. about the relationship between language, enduring emotion, and landscapes, or rather, skyscapes, which Bernardo Soares was fond of describing with exquisite precision. The passage is brief, so I will quote it in its entirety, first of all as it was originally published by various editors, me included:

Tudo se penetra. A leitura dos clássicos, que não falam de poentes, tem-me tornado inteligíveis muitos poentes, em todas as suas cores. Há uma relação entre a competência sintáctica, pela qual se distingue a valia dos seres, dos sons, e das formas, e a capacidade de compreender quando o azul do céu é realmente verde, e que parte de amarelo existe no verde azul do céu.

No fundo é a mesma coisa - a capacidade de distinguir e de subtilizar.

Sem sintaxe não há emoção duradoura. A imortalidade é uma função dos gramáticos (Pessoa I998: text 228).

[Everything is interconnected. My readings of classical authors, who never speak of sunsets, have made many sunsets intelligible to me, in all their colors. There is a relationship between syntactical competence, by which we distinguish the values of beings, sounds, and shapes, and the capacity to perceive when the blue of the sky is actually green, and how much yellow is in the blue green of the sky.

It comes down to the same thing - the capacity to distinguish and to discriminate.

There is no enduring emotion without syntax. Immortality depends on the grammarians] (Pessoa 2002: text 228). 
Translating, reading, and deciphering the text

73

Inv ce penetra. sishope is pent Clovis, fr is

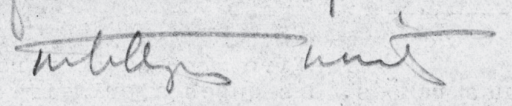
parents en tors os sue cos. the una clever enter a compulenues

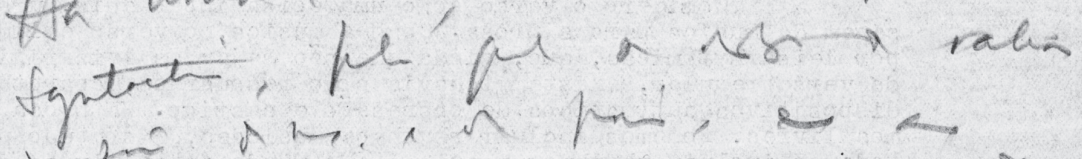

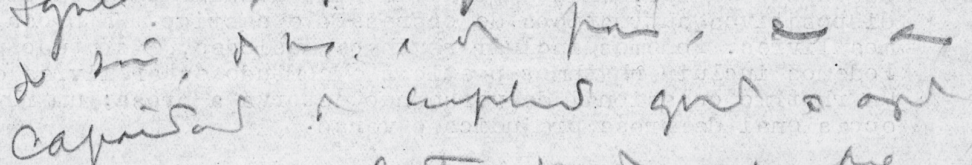

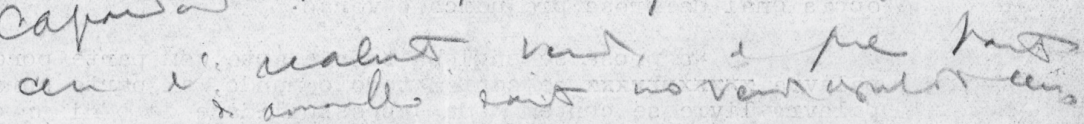
N. font in war cos _ a cifans or inteng-i, de melts.

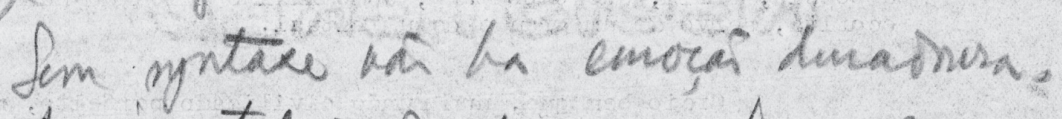
A mimentaloiner i $\mathrm{mm}$ fuse<smiles>C[Tl]</smiles>
promote

FIgURE 5. BNP E3/4-4V.

Around the year 2005, rereading the third sentence of the first paragraph, it occurred to me that the distinction between sevres, sons and formal [beings, sounds and shapes] is not syntactical, as indicated earlier in the sentence; it is substantive, with each of the three nouns indicating a large and independent category. After repeatedly staring at the manuscript (Figure 5) with the idea of

Abriu, 5 (20I6): 65-77

ISS: $2014-8526$, e-ISSN: $2014-8534$. DOL: $10.1344 /$ abriu2oI6.5.5 
syntax lodged behind my eyes, I finally saw what Pessoa had actually written: «a valia do senão, do mas, e do porém». I have translated that sentence into English as: «There is a relationship between syntactical competence, by which we distinguish but from however from nevertheless, and the capacity to perceive when the blue of the sky is actually green, and how much yellow is in the blue green of the sky» (Pessoa 2015: text 228).

Although the various editors of the L. do D. have delimited and articulated the corpus of the book in radically different ways, our readings of the original manuscripts at this point largely coincide. Teresa Sobral Cunha was part of the pioneering team — together with Maria Aliete Galhoz — that undertook the monumental task of transcribing hundreds of passages that had never been published; their work is fundamental to all subsequent editions. My own editorial work resulted in numerous improved readings (there were particularly significant improvements in the eighth edition, from 2009, at which point it was possible to obtain digital copies of Pessoa's manuscripts, greatly facilitating the task of deciphering), and Jerónimo Pizarro made yet other, decisive improvements in the readings for his critical edition (Pessoa 2010). For the most difficult passages, on which there is still no consensus on how they should be read, Teresa Rita Lopes's recent edition (Pessoa 2015) has proposed some new solutions.

5. When editors carefully consider each other's work and still disagree, there is no umpire who can make a sure call. I would argue, however, that in doubtful cases the more plausible calls will be based not only on an analysis of the handwriting but also on our knowledge of how Pessoa writes and on the context in which the words in doubt occur. To illustrate this point, I will resort to the passage from the L. do D. labeled «(Chuva)» [(Rain)] and beginning «E por fim» $[$ And at last $] \ldots$

It is a rainy morning, the shutters are still shut, and Bernardo Soares is still in bed, absolutely horrified at the thought of facing a new day. At the end of the long passage, after much procrastinating, Soares finally goes to the window and opens the shutters «com uma decisão de muita coragem» [with brave determination], then the window itself. And he leans «o pescoço à vida, como a uma canga imensa» [his neck out to life as to an enormous yoke]. And there ends the passage (text 436 in the Assírio \& Alvim and the Penguin editions). The only «problem» word, read different ways by different editors, occurs at the end of the second paragraph. After stating that he feels as if each new day 
Ira. Lum tribunal. Vou ser julgado em cada hoje que he

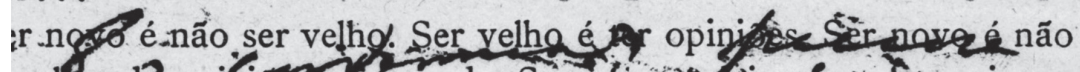

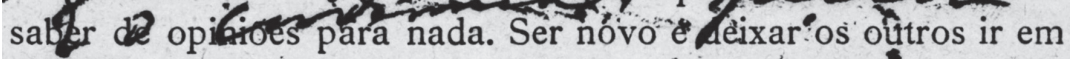
ra o Diabo $\mathrm{cgm}$ as opinióos que teem, Eoas my mas boas or de Gente nanca sábe com quaes é que vaé para o Diabo.

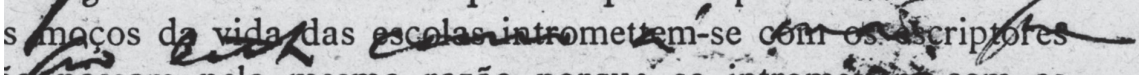
ió passam pela mesma razáo porque se intrometten com as

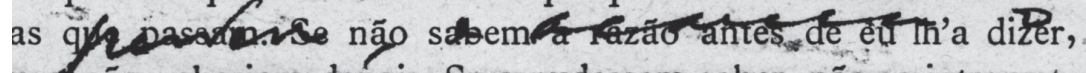
n nâo saberiam depois. S\& a pudessem saber, não se intromet-

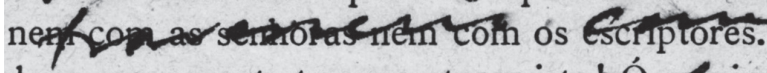
las para a gente ter que aturar isto e gom-ser-Estúdem sciencias, se esładam sciencias; estudem ;e estudam artes; estudem lattas, se estudam lettras. Divirtam-se

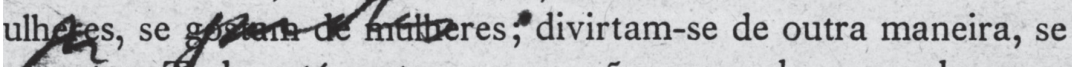
nf outra. Fudo está certo, porque não passa do corpo de quem rte.

Figure 6. Detail of BNP E3/I- $38 v$.

comes to summon him to a court of law where he is going to be judged, Soares — according to the earlier editions, including my own — goes on to say: «E o condenado perene que há em mim agarra-se ao leito como à mãe que perdeu, e acaricia o travesseiro como se a ama o defendesse de gentes» [And the man in me who is perpetually condemned clings to his bed as to the mother he lost, and fondles the pillow as if his nursemaid could protect him from people].

The phrase «de gentes» [from people] does not make much sense, and upon close examination of the original, the penultimate word appears to be «dos» or «das», or possibly «da», but certainly not «de» (Figure 6). Teresa Rita Lopes, accordingly, has pluralized the contracted definite article, but she retains the last word as originally read, resulting in «das gentes», which continues to be highly improbable in terms of the meaning, or rather, in terms of the sort of phraseology typical of Pessoa. In my eighth edition, I rectified the reading to «das portas» [from the shutters]. In their most recent editions, Jerónimo Pizarro and Teresa Sobral Cunha have preferred a different solution: «dos garotos» [from the boys]. The word «garotos» had occurred to me as well, since the first letter of the doubtful word looks a little more like a $g$ than a $p$ (though 
it certainly could be a $p$, as proven by a comparison with the $p$ in perdeu, earlier in the same sentence), and if there were no context - just that one word — I would read it as «garotos». The context made me decide otherwise. True, the «ama» [nursemaid] suddenly makes Bernardo Soares a child, but nowhere in the rest of Pessoa's oeuvre did he ever refer to any experience or express any fear of being beaten up by other children. Were these hypothetical «garotos» wielding sticks or tossing stones, then fair enough.

By contrast, the phrase «das portas» makes eminent sense. There are three other occurrences of «portas» in the passage, twice in the phrase «portas da janela». In fact the «portas» are window shutters - the shutters Soares only opens, with fear and trembling, at the end of the passage. Before that, while still in bed, he holds on to his pillow as to his «ama», deathly afraid of facing the life of the new day lurking behind those shutters.

The two editors who prefer «garotos» could point out that the word occurs further on in the same passage, when Soares imagines everything he has ever dreamed or thought falling to naught among the things of life «como o esqueleto de um cacho de uvas, comido à esquina pelos garotos que o roubaram» [like the skeleton of a bunch of grapes, eaten on the street corner by the boys who stole it]. Could it be because of boys who commit petty larceny that Soares holds on to his pillow-nursemaid for protection? I think it very unlikely. But I might be wrong.

\section{REFERENCES}

Cunha, Teresa Sobral (1993). «Ainda o "Livro do Desassossego"». Revista Colóquio/Letras, $129 / 130,217-220$.

Pessoa, Fernando (1982). Livro do desassossego. Ed. Maria Aliete Galhoz and Teresa Sobral Cunha. Lisbon: Ática.

Pessoa, Fernando (1986). Il libro dell'inquietudine di Bernardo Soares. Transl. Maria José de Lancastre and Antonio Tabucchi. Milan: Feltrinelli.

Pessoa, Fernando (1990). Livro do desassossego por Vicente Guedes, Bernardo Soares. Ed.

Teresa Sobral Cunha. Lisbon: Presença.

Pessoa, Fernando (199I). The book of disquietude. Transl. Richard Zenith. Manchester: Carcanet, I99I

Pessoa, Fernando (1998). Livro do desassossego. Ed. Richard Zenith. Lisbon: Assírio \& Alvim.

PessoA, Fernando (2002). The Book of Disquiet. Transl. Richard Zenith. London: Penguin. 
Pessoa, Fernando (2009). Livro do desassossego composto por Bernardo Soares, ajudante de guarda-livros na cidade de Lisboa. Ed. Richard Zenith. 8a ed. Lisbon: Assírio \& Alvim.

PessoA, Fernando (2010). Livro do desasocego. Ed. Jerónimo Pizarro. Lisbon: Imprensa Nacional-Casa da Moeda.

Pessoa, Fernando (2013). Livro do desassossego. Ed. Teresa Sobral Cunha. Lisbon: Relógio d'Água.

Pessoa, Fernando (2015). Livro(s) do Desassossego. Ed. Teresa Rita Lopes. São Paulo: Global Editora. 